\title{
Zoot Suit
}


This page intentionally left blank 


\section{Zoot Suit}

\section{THE ENIGMATIC CAREER OF AN EXTREME STYLE}

\section{KATHY PEISS}

\section{$\overline{\text { PENN }}$ \\ UNIVERSITY OF PENNSYLVANIA PRESS}

PHILADELPHIA 


\title{
Copyright (C) 2011 Kathy Peiss
}

\author{
All rights reserved. Except for brief quotations used \\ for purposes of review or scholarly citation, none of this \\ book may be reproduced in any form by any means without \\ written permission from the publisher.
}

\author{
Published by \\ University of Pennsylvania Press \\ Philadelphia, Pennsylvania 19104-4112 \\ www.upenn.edu/pennpress \\ Printed in the United States of America \\ on acid-free paper
}

\section{2}

Library of Congress Cataloging-in-Publication Data

Peiss, Kathy.

Zoot suit : the enigmatic career of an extreme style / Kathy Peiss.

p. $\mathrm{cm}$.

Includes bibliographical references and index.

ISBN: 978-0-8122-4337-6 (hardcover : alk. paper)

1. Clothing and dress - Social aspects - United States. 2. Fashion—United

States - History - 20th century. 3. Minority youth-United States-Social life and customs-20th century. I. Title.

GT525.P45 2011

$391^{\prime} .10973-\mathrm{dc} 22$ 
In Memory of Susan Porter Benson 
This page intentionally left blank 
As soon as this man caught sight of her, he began to look himself over. Starting at the bottom with his pointed shoes, he began to look up, lifting his peg-top pants the higher to see fully his bright socks. His coat, long and wide and leaf-green, he opened like doors to see his high-up tawny pants, and his pants he smoothed downward from the points of his collar, and he wore a luminous baby-pink satin shirt. At the end, he reached gently above his wide platter-shaped round hat, the color of a plum, and one finger touched at the feather, emerald green, blowing in the spring winds.

EUDORA WELTY, "LIVVIE IS BACK," 1942

We were unable to find any one thing that started this rage or where it originated.

FRANK WALTON, THREAD OF VICTORY, 1945

Perhaps the zoot suit conceals profound political meaning, perhaps the symmetrical frenzy of the Lindy Hop conceals clues to great potential power-if only Negro leaders would solve this riddle.

RALPH ELLISON, NEGRO QUARTERLY, 1943

A key chain six times too long is just long enough to hold NO keys.

LANGSTON HUGHES, CHICAGO DEFENDER, 1943

It is a symptom of profound weakness in our American civilization.

AGNES E. MEYER, WASHINGTON POST, 1943

Z00T (adj.): exaggerated.

ZOOT SUIT (n.): the ultimate in clothes. The only totally and truly American civilian suit.

CAB CALLOWAY, THE HEPSTER'S DICTIONARY, 1944 
This page intentionally left blank 